\title{
Muskelsykdommer med debut i barnealder
}

\author{
Barn med muskelsykdommer utgjør en viktig gruppe innen barnenevro- \\ logien. Noen av tilstandene er svært alvorlige og krever omfattende \\ tverrfaglig behandling og tilrettelegging. Det er en viss optimisme når \\ det gjelder mulighet for årsaksrettet behandling i noen tilfeller.
}

Nevromuskulære sykdommer er en heterogen gruppe med et stort og økende antall kjente diagnoser. Debutalderen varierer fra før fødselen opp til voksen alder. De mest kjente tilstandene i barnealder er Duchennes muskeldystrofi og spinal muskelatrofi.

Ved en kartlegging i 2005 fant vi en forekomst av nevromuskulære sykdommer på 35,6 per 100000 innbyggere under 18 år (1). Utenlandske studier viser lignende eller noe høyere tall. De fleste tilstandene er genetisk betinget. Mye er felles for de nevromuskulære sykdommene, det gjelder både kliniske manifestasjoner og behandlingsprinsipper, men i denne artikkelen vil vi av plasshensyn konsentrere oss om tilstander som rammer selve muskelcellene eller den nevromuskulære overgang (fig 1). Av disse tilstandene omtaler vi mer spesielt dem som er blant de mest sentrale i barnefeltet.

$\mathrm{Vi}$ omtaler ikke spinal muskelatrofi, Guillain-Barrés syndrom og perifere nevropatier hvor forhornceller, nerverøtter og perifere nerver er involvert. Vi omtaler heller ikke inflammatoriske myopatier. Det følgende bygger på aktuelle artikler på området og på forfatternes egne erfaringer. Vi håper å nå leger som kan treffe på disse pasientene, men som ikke ser dem så ofte.

\section{Utredning av muskelsykdommer hos barn}

En grundig klinisk vurdering må alltid danne utgangspunktet for diagnostisering. Et hovedspørsmål er hvorvidt det ses tegn til muskelsvakhet. Hos spedbarn gir hypotoni (floppy infant) mistanke om nevromuskulær sykdom, men i de fleste tilfeller er det andre årsaker til hypotonien. Det kan være tidlig stadium av cerebral parese, Prader-Willis syndrom eller generalisert sykdom.

Hos litt større barn kan sen oppnåelse av selvstendig gangfunksjon eller redusert evne til å hoppe, hinke eller gå i trapp vekke mistanke (ramme 1). Andre aktuelle symptomer er tegn på svakhet i hender eller armer, svelgevansker, dysartri, redusert ansiktsmimikk, ptose, oftalmoplegi, respirasjonsvansker, kontrakturer eller skoliose.

Måling av kreatinkinase (CK) er viktig ved noen muskelsykdommer, men normalt nivå utelukker ikke muskelaffeksjon. Ved klar mis- tanke basert på kliniske funn og eventuelt kreatinkinasenivå bør barnet henvises til barneavdeling/nevropediater (ramme 2).

Nevrofysiologiske tester (elektromyografi - som gjør vondt! - og nevrografi) egner seg til å avklare om sykdommen rammer perifere nerver, nevromuskulær overgang eller selve muskelcellen, men skiller ofte ikke godt mellom ulike muskelsykdommer. Mange muskelsykdommer vil gi samme type forstyrrelse ved elektromyografi, derfor vil resultatet ikke kunne si hvilken sykdom som foreligger.

Muskelbiopsi er fortsatt viktig i mange tilfeller. Vi har nå har gode rutinemessige gentester for Duchennes muskeldystrofi og Beckers muskeldystrofi, skulder-hofte-muskeldystrofi (limb girdle muscular dystrophy) 2I og dystrophia myotonica, likeså for spinal muskelatrofi, som ofte er en viktig differensialdiagnose til myopatiene. Når disse diagnosene bekreftes ved gentest, behøves vanligvis ikke biopsi for å stille diagnosen. I økende grad blir genpaneler tatt bruk, hvor det analyseres et stort antall gener i samme prøve. Men muskelbiopsi kan fortsatt være nødvendig for å tolke resultatet ved slike panelanalyser.

Genetisk veiledning er viktig for foreldre som får vite at deres barn har en genetisk betinget muskelsykdom.

\section{Generelt om behandling}

Unntaksvis, som ved ulike typer myastenier og ved inflammatoriske myopatier, kan effektiv medikamentell behandling tilbys. Særlig ved Duchennes muskeldystrofi satses det mye internasjonalt på utprøvning av medikamenter som har en mer årsaksrettet virkning $(2,3)$. Mange foreldre er svært godt informert om disse utprøvningene. Det er viktig å informere om at det som er eksperimentell behandling, også kan innebære risiko for uventede negative effekter. Uansett er det en optimisme i miljøet med hensyn til fremtidig mulighet for mer effektiv årsaksrettet terapi.

Behandlingen av muskelsykdommer hos barn er utpreget tverrfaglig. Fysioterapi er en hjørnesten. Bistand fra ergoterapeut kan også være av avgjørende betydning. Ortopediske tiltak er ofte nødvendig. Ved mange av tilstandene rammes respirasjonsmuskulatur,

\author{
Petra Aden \\ Seksjon for nevrohabilitering \\ Oslo universitetssykehus \\ Ellen J. Annexstad \\ Enhet for medfødte og arvelige nevromuskulære \\ tilstander (EMAN) \\ Oslo universitetssykehus \\ og \\ Barne- og ungdomsklinikken \\ Sykehuset Østfold

\section{Espen Lien} \\ Barne- og ungdomsklinikken \\ og \\ Trondsletten habiliteringssenter \\ St. Olavs hospital \\ og \\ Institutt for laboratoriemedisin \\ barne- og kvinnesykdommer \\ Norges teknisk-naturvitenskapelige universitet \\ Jasmina Majkic Tajsic \\ Barnehabiliteringen \\ Barne- og ungdomsklinikken \\ Universitetssykehuset Nord-Norge

\section{Nanette Mjellem} \\ Nasjonalt kompetansesenter for \\ hjemmerespiratorbehandling \\ Haukeland universitetssykehus

\section{Magnhild Rasmussen} \\ marasmus@ous-hf.no \\ Barneavdeling for nevrofag \\ og \\ Enhet for medfødte og arvelige nevromuskulære \\ tilstander \\ Oslo universitetssykehus
}

\section{HOVEBUDSKAP}

Muskelsykdommer med debut i barnealder er ofte genetisk betinget og representerer til dels svært alvorlige tilstander med stor sykdomsbyrde over mange år

Ved mistanke om svekket muskelkraft kan fastlegen få viktig informasjon ved å måle CK-nivå, men normalt nivå utelukker ikke muskelsykdom

Videre diagnostikk bør skje i regi av spesialist med barnenevrologisk kompetanse

Behandlingen er i høy grad tverrfaglig 
eventuelt hjertemuskel, og oppfølging av hjerte- og lungefunksjon er viktig for å kunne sette i verk relevant behandling til rett tid.

Narkose skal så langt som mulig planlegges godt hos pasienter med muskelsykdom, og hjerte- og lungefunksjon bør da være vurdert $\mathrm{i}$ forkant. Ved noen myopatier er det risiko for å utvikle malign hypertermi eller lignende reaksjoner $\mathrm{i}$ forbindelse med narkose. Det gjelder blant annet Duchennes muskeldystrofi.

Ernæringen bør optimaliseres. Gastrostomi er til stor hjelp for noen. Man bør være spesielt oppmerksom på tannhelsen, da det blant annet kan være motoriske vansker med tannpuss eller feilstillinger i kjeve. Spesialistkompetanse kan bli nødvendig i tannbehandlingen.

I tillegg kommer behovet for psykososial og pedagogisk oppfølging. Det er en stor psykisk belastning for barn og unge å oppleve økende motorisk svikt samtidig som vennene i økende grad er opptatt av gode motoriske ferdigheter.

\section{Duchennes muskeldystrofi og Beckers muskeldystrofi}

Begrepet «muskeldystrofi» henspiller generelt på typiske funn i muskelbiopsi som uttrykk for en degenerativ prosess, ofte med en økning av CK-nivået i blodet.

Duchennes muskeldystrofi arves X-bundet. Dette er den vanligste muskelsykdommen i barnealder, med en forekomst på én per $3600-6000$ levendefødte gutter (4). I omtrent to tredeler av tilfellene skyldes sykdommen en mutasjon nedarvet fra mor, hos de øvrige er mutasjonen nyoppstått.

Sykdommen debuter gjerne i 2-3-årsalderen, eventuelt med milde tegn tidligere (5). Disse guttene lærer ikke å løpe normalt og kan sjelden hinke. Typisk hos mange er tykke legger som uttrykk for muskelpseudohypertrofi. Ofte utvikles stramme hælsener med tendens til tågang. Positiv Gowers' manøver (fig 2) er et viktig klinisk tegn på svak hoftemuskulatur. Med tiden utvikles svakhet også i overekstremitetene, og det er risiko for skoliose. Også respirasjonsmuskler rammes, og etter hvert får mange tegn på kardiomyopati. Hos omtrent en tredel finnes en ikke-progredierende mental retardasjon, og forekomsten av nevropsykiatriske lidelser er noe $ø \mathrm{kt}(6,7)$.

Genfeilen ved Duchennes muskeldystrofi rammer produksjonen av dystrofin, som er et strukturelt protein i muskelcellene. Dette fører til membraninstabilitet og degenerering av muskelfibrene. Ved Duchennes muskeldystrofi måles det et femsifret kreatinkinasenivå. Kvinnelige bærere kan ha milde muskelsymptomer og lett økt kreatinkinasenivå i blodet. Det er viktig å vite at noen av dem utvikler kardiomyopati. Bærere skal derfor følges kardiologisk.

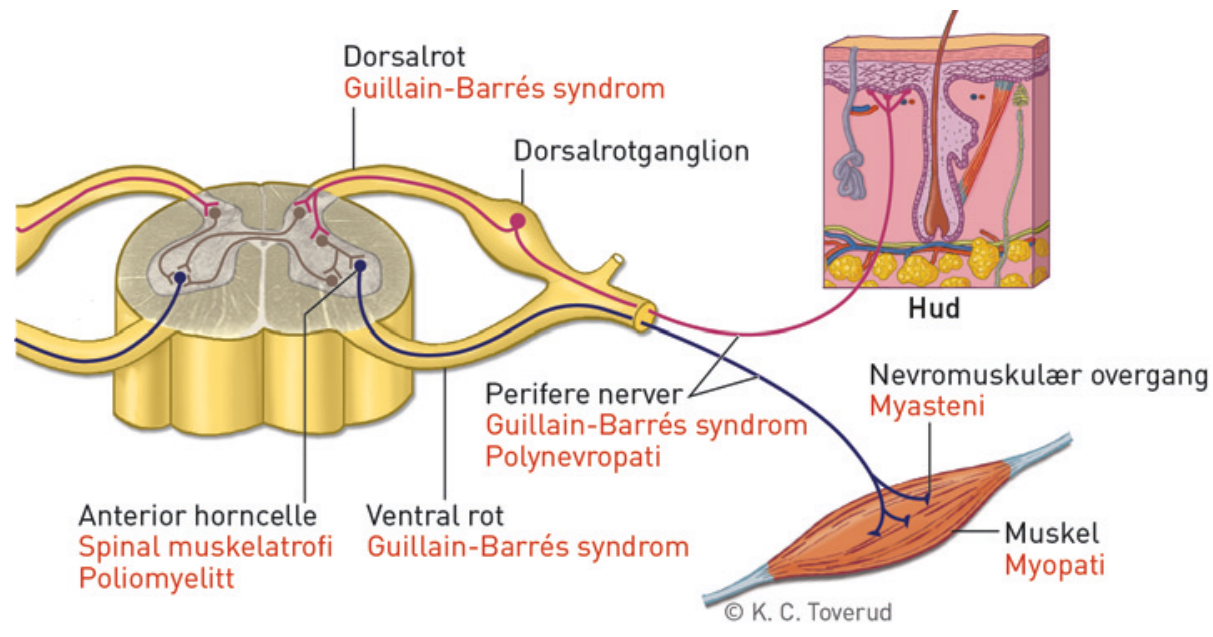

Figur 1 Forenklet fremstilling av lumbale ryggmargsstrukturer (svart) og tilhørende nevromuskulære sykdomsbilder (rødt)

Selv om man ikke kan påvise at mor er bærer, kan det foreligge gonademosaikk. Genetisk veiledning er viktig, ikke minst når det gjelder informasjon om gjentagelsesrisikoen.

I tillegg til behandling som skissert over se også Bushby og medarbeidere (8) - anbefales det ved Duchennes muskeldystrofi å starte glukokortikoidbehandling allerede i tidlig fase av sykdommen (4). Tidligere mistet gutter med sykdommen gangfunksjonen senest ved 10-12 års alder. Med steroidbehandling kan den bevares kanskje et par år til. Eventuelt bremses også utviklingen av respirasjonsproblematikk og kardial affeksjon, og det ser ut til at forekomsten av behandlingstrengende skoliose avtar. Likevel må bivirkninger av steroidbehandlingen, blant annet overvekt og redusert lengdevekst, monitoreres jevnlig og veies opp mot nytten av behandlingen for den enkelte pasient.

Levealderen er redusert, særlig som følge av sviktende hjerte- og lungefunksjon (9).

Beckers muskeldystrofi er en mildere form for dystrofinopati. Klinisk er det et kontinuum mellom Duchennes muskeldystrofi og Beckers muskeldystrofi. Kreatinkinasenivået er økt også ved Beckers muskeldystrofi. Fenotypen varierer. Noen blir rullestolavhengige før 20 års alder, andre kan bevare gangfunksjon til etter fylte 50 år. Pasientene har ikke samme tendens til mental retardasjon som ved Duchennes muskeldystrofi (10), mens det er en klar risiko for kardiomyopatiutvikling, også der gangfunksjonen er bevart.

\section{Skulder-hofte-muskeldystrofier}

Per i dag er det beskrevet rundt 30 ulike undergrupper av muskeldystrofier med en proksimal (skulder-hofte) distribusjon av muskelsvakhet. Mange av dem svært sjeldne.
Type 1 arves autosomalt dominant, type 2 arves autosomalt recessivt. Den vanligste undergruppen i Norge er type 2I, med mutasjon i FKRP-genet.

Symptomdebut for type 2I kan ses fra småbarnsalder til opp i voksen alder. Kreatinkinasenivået er vanligvis økt også før symptomdebut, og hos barn er det ikke sjelden at utredning av en tilfeldig oppdaget høy verdi fører til diagnosen av type 2I. Denne sykdommen er langsomt progredierende. Muskelsmerter forekommer ofte, i tillegg til muskelsvakhet. Ved skulder-hofte-muskeldystrofi 2I kan det utvikles kardiomyopati.

\section{Andre muskeldystrofier med debut etter spedbarnsalder}

Her skal nevnes Emery-Dreifuss' muskeldystrofi, som også er sjelden, men som, for øvrig i likhet med skulder-hofte-muskeldystrofi 1B, innebærer høy risiko for alvorlig hjerteaffeksjon (11). Emery-Dreifuss' muskeldystrofi arves ofte X-bundet. Typisk

\section{RAMME 1}

Symptomer ved muskelsykdommer hos barn

Muskelsvakhet

Atrofi og pseudohypertrofi av muskulaturen

Liten utholdenhet ved fysisk aktivitet

Forsinket motorisk utvikling

Gowers' tegn (fig 2)

Redusert mimikk

$\emptyset$ kning i kreatinkinasenivå (CK) - OBS normal verdi utelukker ikke muskelsykdom) 
RAMME 2

Forfatternes anbefalte undersøkelser og henvisninger

\section{Fastlege}

Anamnese/klinisk undersøkelse - tegn til muskelsvakhet?

CK-nivå

\section{Barnelege}

Anamnese/klinisk undersøkelse

Involver fysioterapeut for testing

DNA-test ved mistanke om Duchennes muskeldystrofi, dystrophia myotonica, skulderhofte-muskeldystrofi 2I, spinal muskelatrofi

Acetylkolinreseptorantistoff ved mistanke om myasteni

Ev. EMG/nevrografi ved mistanke om myasteni/nevropati

\section{Nevropediater}

CK-nivå, ev. acetylkolinreseptorantistoff

EMG/nevrografi ved normal CK-verdi

Ev. MR-undersøkelse av muskulatur

Genpanel dersom lett tilgjengelige enkeltgentester er negative

Muskelbiopsi (noen ganger før genpanel)

Oppfølging i samarbeid med andre spesialister (f.eks. hjerte, lunge, ortopedi), barnehabilitering og lokale instanser når myopatidiagnosen er stilt

OBS Barnerevmatolog er sentral ved utredning og behandling av inflammatoriske myopatier for denne tilstanden er utvikling av albuekontrakturer og stivhet i ryggen.

Facioscapulohumeral muskeldystrofi arves autosomalt dominant og er blant de vanligere muskeldystrofiene. Debutalderen er oftest før 20 år, men sjelden i tidlig barnealder. Tilstanden er langsomt progredierende, og det er normal livslengde.

\section{Kongenitte muskeldystrofier og kongenitte myopatier}

Det tradisjonelle skillet mellom kongenitte muskeldystrofier og kongenitte myopatier er basert på funn i muskelbiopsi. Typisk for dystrofiene er fibrose og nekrose, mens de kongenitte myopatiene blant annet kan ha patologiske strukturer i muskelcellene, noe som gjenspeiles i navn som nemalinmyopati og «central core»-myopati. Etter hvert er det beskrevet mange undergrupper. Det viser seg at én genotype kan gi flere fenotyper og at én fenotype kan skyldes mutasjon i ulike gener (12).

Kreatinkinasenivået er oftere økt og symptomene oftere progredierende ved dystrofiene enn ved myopatiene. Symptomer er oftest til stede ved fødselen eller melder seg i løpet av de første månedene ved kongenitte muskeldystrofier, men iblant noe senere. Noen av disse innebærer alvorlig affeksjon også av hjerne og øyne (13).

De kongenitte myopatiene $(14,15)$ utgjør også en heterogen gruppe. I noen tilfeller kan barnets tilstand være svært alvorlig allerede ved fødselen, med uttalt hypotoni og muskelsvakhet og behov for respiratorbehandling og sondeernæring, og livslengden kan være svært begrenset. Dette gjelder undergruppen X-bundet myotubulær myopati og i noen tilfeller nemalinmyopati. Det finnes mildere former for nemalinmyopati med tydelige symptomer først i småbarnsalderen.

Pasienter med kongenitte myopatier kan holde seg klinisk relativt stabile. Ved «central core»-myopati er det også stor variasjon i alvorlighetsgrad. Mutasjonen sitter her i RYRl-genet, et gen som også er assosiert med risiko for malign hypertermi.

\section{Dystrophia myotonica type 1}

Ved myotoni foreligger det redusert evne til muskelavslapning etter kontraksjon. Dystrophia myotonica er en multisystemsykdom som, i tillegg til å ramme motorikken, kan gi kognitiv affeksjon, ulike endokrine forstyrrelser og ikke minst hjerteaffeksjon. Genfeilen består i økt antall CTG-repetisjoner i et område på kromosom 19. Diagnosen stilles ved gentest. Kongenitt dystrophia myotonica er en alvorlig tilstand, som ofte innebærer behov for både respiratorbehandling og sondeernæring initialt.

Ved kongenitt debut er sykdommen som oftest arvet fra mor, som selv kan ha kun milde symptomer og ikke nødvendigvis er klar over sin tilstand. Genfeilen kan utvides for hver generasjon, og ved neonatal debut er det mer enn 1000 repetisjoner, mot normalt færre enn 50. Overlever disse barna de første ukene, blir de gjerne bedre og kan lære å gå, men som oftest er de mentalt retardert. Etter hvert utvikles tegn på klassisk dystrophia myotonica.

Det er viktig å vite at myotonien oftest ikke avdekkes i tidlig barnealder. Ved debut senere er det ofte atferdsvansker og lærevansker som først gjør seg gjeldende (16). Selv om en diagnostisk gentest er lett tilgjengelig, kan det gå lang tid før riktig diagnose blir stilt og barna blir forstått på riktig måte. Tarmsymptomer kan også være plagsomme
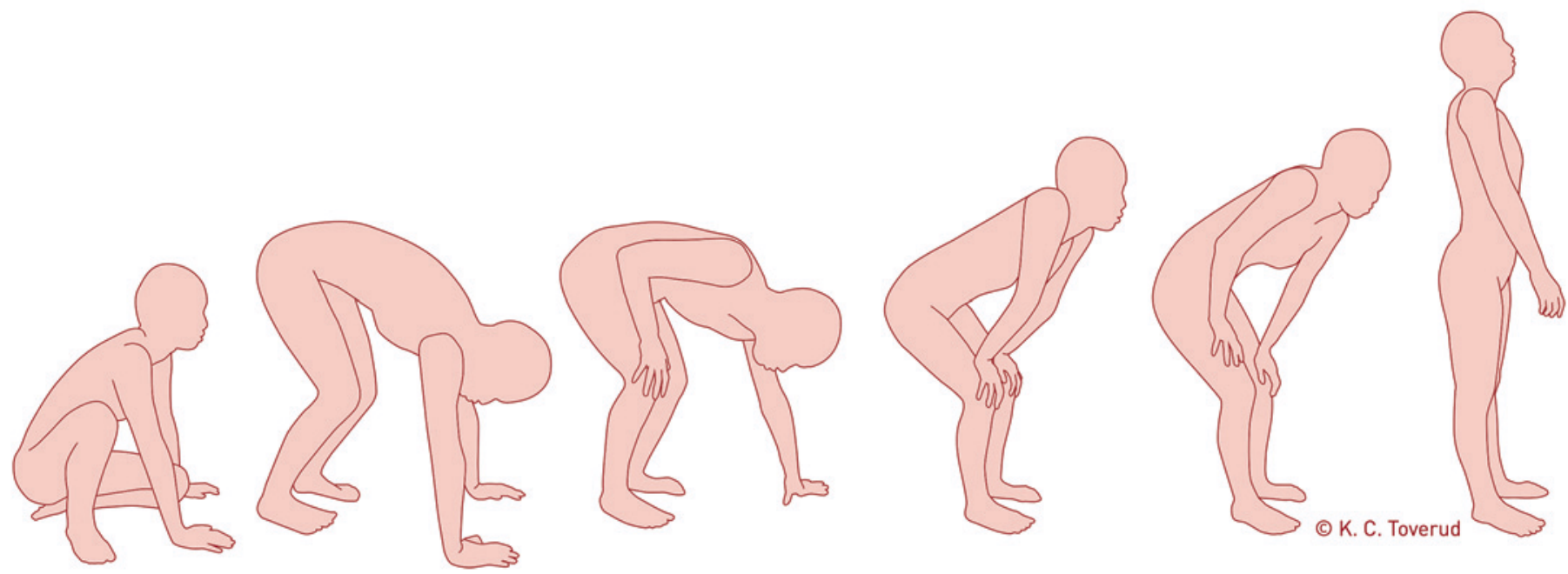

Figur 2 Gowers' tegn demonstrerer hvordan en person reiser seg når det er svak kraft i proksimal muskulatur i underekstremitetene 
i barnealder. Hjertearytmi er en fryktet komplikasjon.

\section{Myasteni}

Myasteni rammer den nevromuskulære overgangen og gir typisk økt trettbarhet. Ved neonatal myasthenia gravis er antistoffer mot acetylkolinreseptorer overført fra moren i svangerskapet. Av barn til affiserte mødre vil 10-20\% straks etter fødselen vise symptomer på muskelsvakhet (17). Disse symptomene er forbigående, men intensivbehandling kan være nødvendig initialt.

Myasthenia gravis som melder seg senere i barneårene, ligner den voksne formen. Diagnosen stilles ved nevrofysiologisk undersøkelse og ved påvisning av antistoffer. Hos barn er imidlertid ikke alltid antistoffer påvisbare, selv om det dreier seg om autoimmun myasteni. Diagnosen er viktig å stille, da tilstanden kan behandles effektivt medikamentelt. Oftest gjøres også tymektomi.

I de senere år har man fått økt kunnskap om de kongenitte myasteniene (18). Her finnes mange undergrupper, og mange ulike gener er involvert. Disse tilstandene viser seg som regel ved fødselen eller i spedbarnsalderen. Typisk er muskelsvakhet som øker ved muskelbruk, oftalmoplegi, spisevansker, apnéepisoder og kontrakturer. Klinisk kan de ligne kongenitte myopatier. Kongenitte myastenier er viktige å diagnostisere, da mange kan behandles medikamentelt. Korrekt diagnose er viktig for behandlingsvalget.

\section{Konklusjon}

Muskelsvakhet er kjernesymptom ved flere muskelsykdommer som debuterer i barneårene. Vi har gitt en utvalgt oversikt over noen av de viktigste. For allmennpraktikeren er det avgjørende å ta en grundig anamnese (inkludert familieanamnese) og klinisk undersøkelse, måle kreatinkinaseverdi og henvise til barneavdeling/nevropediater ved mistanke om underliggende sykdom.

\section{Petra Aden (f. 1966)}

er spesialist i barnesykdommer, med spesialkompetanse i barnenevrologi og habilitering. Hun har ph.d.-grad i eksperimentell nevrologisk forskning på umodne nerveceller og steroidpåvirkning og er seksjonsleder og overlege. Forfatter har fylt ut ICMJE-skjemaet og oppgir ingen interessekonflikter.

\section{Ellen J. Annexstad (f. 1973)}

er spesialist i barnesykdommer, med spesialkompetanse i barnenevrologi, overlege og ph.d.-stipendiat. Hun kartlegger pasienter under 18 år med Duchennes muskeldystrofi. Forfatter har fylt ut ICMJE-skjemaet og oppgir ingen interessekonflikter.

\section{Espen Lien (f. 1957)}

er spesialist i barnesykdommer, med spesialkompetanse i barnenevrologi. Han er overlege, ph.d. og er førsteamanuensis.

Forfatter har fylt ut ICMJE-skjemaet og oppgir ingen interessekonflikter.

\section{Jasmina Majkic Tajsic (f. 1962)}

er spesialist i barnesykdommer, med spesialkompetanse i barnenevrologi og habilitering. avdelingsoverlege og styremedlem i Norsk barnenevrologisk forening

Forfatter har fylt ut ICMJE-skjemaet og oppgir ingen interessekonflikter.

\section{Nanette Mjellem (f. 1953)}

er spesialist i barnesykdommer og overlege. Forfatter har fylt ut ICMJE-skjemaet og oppgir ingen interessekonflikter.

\section{Magnhild Rasmussen (f. 1951)}

er dr.med., spesialist i barnesykdommer og overlege.

Forfatter har fylt ut ICMJE-skjemaet og oppgir ingen interessekonflikter.

Litteratur

1. Rasmussen M, Risberg K, Vøllo A et al. Neuromuscular disorders in children in South-Eastern Norway. J Pediatr Neurol 2012; 10: 095-100.

2. Bushby K, Finkel R, Wong B et al. Ataluren treatment of patients with nonsense mutation dystrophinopathy. Muscle Nerve 2014: 50: 477-87.

3. Voit T, Topaloglu H, Straub V et al. Safety and efficacy of drisapersen for the treatment of Duchenne muscular dystrophy (DEMAND II): an exploratory, randomised, placebo-controlled phase 2 study. Lancet Neurol 2014: 13: 987-96.

4. Bushby K, Finkel R, Birnkrant DJ et al. Diagnosis and management of Duchenne muscular dystrophy, part 1: diagnosis, and pharmacological and psychosocial management. Lancet Neurol 2010, 9. 77-93.

5. Annexstad EJ, Lund-Petersen I, Rasmussen M. Duchennes muskeldystrofi. Tidsskr Nor Legeforen 2014; 134: $1361-4$

6. Cotton S, Voudouris NJ, Greenwood KM. Intelligence and Duchenne muscular dystrophy: full-scale, verbal, and performance intelligence quotients. Dev Med Child Neurol 2001; 43: 497-501.

7. Ricotti V, Mandy WP. Scoto M et al. Neurodevelop mental, emotional, and behavioural problems in Duchenne muscular dystrophy in relation to under- lying dystrophin gene mutations. Dev Med Child Neurol 2016; 58: 77-84.

8. Bushby K, Finkel R, Birnkrant DJ et al. Diagnosis and management of Duchenne muscular dystrophy, part 2: implementation of multidisciplinary care. Lancet Neurol 2010; 9: 177-89.

9. Van Ruiten HJ, Marini Bettolo C. Cheetham T et al. Why are some patients with Duchenne muscular dystrophy dying young: An analysis of causes of death in North East England. Eur J Paediatr Neurol 2016: 20: 904-9.

10. Young HK, Barton BA, Waisbren $\mathrm{S}$ et al. Cognitive and psychological profile of males with Becker muscular dystrophy. J Child Neurol 2008; 23: 155-62.

11. Hermans MC, Pinto YM, Merkies IS et al. Hereditary muscular dystrophies and the heart. Neuromuscul Disord 2010; 20: 479-92.

12. Kaplan JC, Hamroun D. The 2016 version of the gene table of monogenic neuromuscular disorders (nuclear genome). Neuromuscul Disord 2015; 25: $991-1020$

13. Kang PB, Morrison L, lannaccone ST et al. Evidence-based guideline summary: evaluation, diagnosis, and management of congenital muscular dystrophy: Report of the Guideline Development Subcommittee of the American Academy of Neurology and the Practice Issues Review Panel of the American Association of Neuromuscular \& Electrodiagnostic Medicine. Neurology 2015; 84: 1369-78.

14. North KN. Clinical approach to the diagnosis of congenital myopathies. Semin Pediatr Neurol 2011; 18: 216-20

15. Colombo I, Scoto M, Manzur AY et al. Congenital myopathies: Natural history of a large pediatric cohort. Neurology 2015; 84: 28-35

16. Ekström AB, Hakenäs-Plate L, Tulinius $M$ et al. Cognition and adaptive skills in myotonic dystrophy type 1: a study of 55 individuals with congenital and childhood forms. Dev Med Child Neurol 2009: 51. 982-90.

17. Papazian 0. Transient neonatal myasthenia gravis J Child Neurol 1992; 7: 135-41.

18. Finlayson S, Beeson D. Palace J. Congenital myasthenic syndromes: an update. Pract Neurol 2013 13: 80-91.

Mottatt 21.7. 2016, første revisjon innsendt 28.10. 2016, godkjent 15.12. 2016. Redaktør: Ketil Slagstad. 